Article

\title{
A Sustainable Approach for the Refurbishment Process of Vernacular Heritage: The Sesga House Case Study (Valencia, Spain)
}

\author{
Camilla Mileto ${ }^{1, *(\mathbb{D}}$, Fernando Vegas $\left.{ }^{1} \mathbb{(}\right)$, Carmen Llatas ${ }^{2}\left(\mathbb{D}\right.$ and Bernardette Soust-Verdaguer ${ }^{2}$ \\ 1 ETS Arquitectura, Universitat Politècnica de València, 46022 València, Spain; fvegas@cpa.upv.es \\ 2 ETS Arquitectura, Universidad de Sevilla, 41004 Sevilla, Spain; cllatas@us.es (C.L.); bsoust@us.es (B.S.-V.) \\ * Correspondence: cami2@cpa.upv.es
}

Citation: Mileto, C.; Vegas, F.; Llatas, C.; Soust-Verdaguer, B. A Sustainable Approach for the Refurbishment

Process of Vernacular Heritage: The Sesga House Case Study (Valencia, Spain). Sustainability 2021, 13, 9800. https://doi.org/10.3390/su13179800

Academic Editors: John Carman and Miguel Amado

Received: 11 July 2021

Accepted: 24 August 2021

Published: 31 August 2021

Publisher's Note: MDPI stays neutral with regard to jurisdictional claims in published maps and institutional affiliations.

Copyright: (C) 2021 by the authors. Licensee MDPI, Basel, Switzerland. This article is an open access article distributed under the terms and conditions of the Creative Commons Attribution (CC BY) license (https:/ / creativecommons.org/licenses/by/ $4.0 /)$.

\begin{abstract}
The refurbishment of traditional vernacular architecture is currently of interest for the conservation of heritage, historic landscape and cultural landscape, as well as for its potential benefits in the field of environmental sustainability. The carefully selected materials and techniques used in the refurbishment of a traditional dwelling in Sesga (Valencia, Spain) maintain the local construction techniques while causing the least possible environmental impact, saving on transport and transformation and construction energy. This article uses LCA to showcase this contribution, examining three scenarios: the first option is the refurbishment of the case study using natural traditional materials and techniques; the second presents a hypothetical refurbishment using widely used industrial materials; and a third option looks at the demolition of the existing building and the addition of a new construction with widely used industrial materials. This comparison has shown where and why the first option is, broadly speaking, the most sustainable option in environmental, sociocultural and socioeconomic terms.
\end{abstract}

Keywords: life cycle assessment; local materials; natural materials; refurbishment; traditional techniques; sustainability; vernacular architecture

\section{Introduction}

Given the threat of worsening climate change, the need for energy saving and for a reduction in $\mathrm{CO}_{2}$ emissions is currently a priority at a European and a global level [1], as reflected in the signing of the European Green Deal [2]. According to official data from the European Union, over $40 \%$ of energy consumption is due to the heating and cooling of housing [3]. However, the construction process also represents a sizeable expenditure in energy in the extraction, production and transport of building materials, as well as in the supposition of a phase of possible amortisation at the end of the life cycle in actions for the demolition and elimination of waste [4].

As is known, the numerous historic buildings of great heritage value are the bases of our history, culture and identity [5]. Many of these buildings are now, or once were, dwellings standing alone or in groups in rural settlements or historic centres, and their refurbishment is essential for the conservation of our history and identity [5,6]. This vernacular heritage architecture is not only important as a sign of identity linked to the landscape where it is born, but also for lessons in sustainability, which several authors have been promoting since the 1980s [7-10], according to the bibliographical review [11-14]. In this regard, it is worth highlighting the project "VerSus: Lessons from Vernacular Heritage in Sustainable Architecture", co-funded by the European Union between 2012 and 2014, which summarised the lessons in environmental, sociocultural and socioeconomic sustainability provided by vernacular architecture in 15 parameters, allowing the analysis of vernacular architecture cases and providing guidelines for the architectural design of new constructions [15]. The conservation of this architecture is therefore important for the 
preservation of material, cultural and popular identity, offering continued inspiration with examples in sustainability [16]. This project promotes international conferences focusing on these topics and becoming a source of major reflections in the field [17-19]. This topic has also been covered in other publications on an international scale [20].

In this context, it can be stated that vernacular architecture should be analysed over a long life cycle, which begins with a construction phase with traditional materials and techniques, including several phases for use and transformation over history, ending with definitive abandonment and amortisation. Within this extensive life cycle, the phases for refurbishment actions and contemporary use have most impact in terms of use of energy and resources. In this respect, the conservation of vernacular architecture is faced with two major concerns worldwide: the improvement in energy efficiency in the existing housing stock and the reduction in the carbon footprint during the life cycle of architecture.

Regarding the first point, the extensive literature addresses the improvement of energy efficiency in the retrofitting of buildings. Nevertheless, almost all cases focus on housing built after the 1950s, according to the bibliographical reviews [21,22]. Although these studies are of interest in the measurement and quantification of energy efficiency in existing buildings [23], they are somewhat limited in the application to buildings with heritage value which require the application of conservation criteria [24]. Therefore, the notable differences between these refurbishments and conservation interventions on heritage buildings [25] make it necessary to resort to other tools and guidelines used in the field of conservation [26], proposing practical examples of interventions for the improvement of energy efficiency in heritage and vernacular buildings. In parallel, several studies confirm the energy-efficient qualities of vernacular architecture as a type of architecture adapted to local surroundings and climate $[18,19]$. It could therefore be said that interventions for improving energy efficiency in historic and vernacular buildings could be minimised, in turn reducing their potential impact on heritage buildings $[13,14]$. On the contrary, transformations such as floods or stronger rains derived from climate change are putting this vernacular adaptation to the climate to the test, so that the adaptation of heritage to climate change is beginning to create new needs, questions and reflections $[27,28]$.

In terms of the reduction in the $\mathrm{CO}_{2}$ emissions of architecture during its life cycle, it is increasingly claimed that the refurbishment, conservation, retrofitting and adaptation of existing architecture are more sustainable processes in terms of the environment and their possible effect on climate change than their demolition in order to build new constructions [29-31]. Thus, there are growing numbers of guides and measures to prevent the production of $\mathrm{CO}_{2}$ as much as possible in building construction [31-34]. However, in terms of LCA application to the retrofitting processes, once again these are mostly dwellings dating from the mid-20th century, according to the bibliographical review [35-37], and there are extremely few cases of this assessment being applied to heritage buildings [38,39]. In the field of restoration and refurbishment of heritage architecture, different criteria entail the use of different types of traditional and industrial materials and techniques, [24] and the impact on the environment can vary widely depending on the options, techniques and materials adopted in the project $[23,40]$. In addition, the conservation of a heritage dwelling always prompts difficulties among all those taking part in the process (owner, developer, administration, etc.), given a lack of knowledge of the processes both during the intervention in the structure and the operation using traditional materials and techniques, as used in the past where they were part of local ancestral construction techniques found in the immediate surroundings [41].

There are still a few examples of refurbishment of vernacular architectures performed with traditional materials with the objective of preserving authenticity and, among them, fewer still which pretend to clearly demonstrate the impact that these alternatives from the conservation project have on $\mathrm{CO}_{2}$ emissions into the environment [26]. Bearing this in mind, this article aims to show that firstly, it is possible to use traditional materials and techniques in the conservation of traditional housing, and secondly, that the use of these traditional materials and techniques can impart major energy reduction in the conservation phase. 
This study aims to demonstrate the advantages of the refurbishment process of a singlefamily house following a global sustainability approach, including qualitative criteria such as the parameters of the VerSus Programme and the Sustainable Development Goals or SDGs and quantitative criteria such as Life Cycle Assessment or LCA. The novelty of the present study lies not only in the integration of both criteria, but also in the subject of the study, a simple vernacular dwelling, representative of most of the global traditional housing stock. The advantages highlighted in this study, applied individually and independently by owners of these homes, could provide significant change in terms of socioeconomic benefit and Climate Action.

\section{Materials and Methods}

This text aims to compare the impact and results of carrying out conservation actions both for the community and environment, analysing the conservation budget of the structure and materials to complete the building's life cycle. A conservation project was drawn up and implemented for a real existing vernacular dwelling, based mostly on the use of the same traditional techniques used in the construction of these houses and the actual proximity materials. This document (Figure 1) came to be the basis of a pilot conservation project whose results could be applicable to the conservation of other vernacular dwellings in the region, and in turn, to vernacular architecture in general. The proposal of this pilot project was awarded 1st Prize in the European Heritage Awards/Europa Nostra Awards 2003 [42].
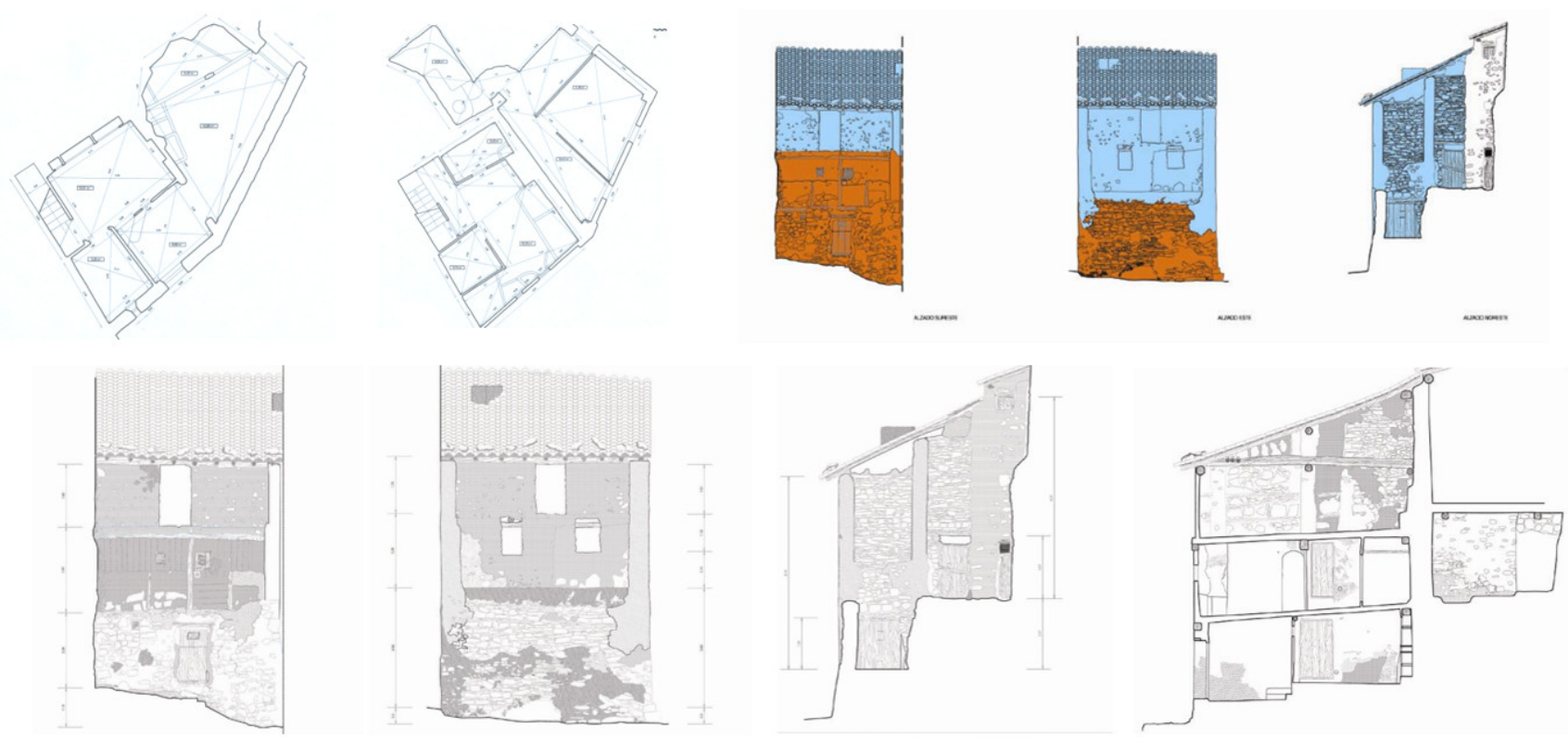

Figure 1. Extract of the preliminary study done for the vernacular house at Sesga (Rincón de Ademuz, Valencia, Spain): survey (layouts, up; facades and sections, bottom) and study of the different construction phases (in orange, first phase, 18th century; in blue, second phase, beginning of 20th century). Credits: C.M., F.V.

Recently, a survey of the village has been carried out to know the type of interventions that have been carried out to date: refurbishments made with traditional materials, as is the case with this pilot intervention, refurbishments made with industrial materials and construction of completely new buildings with conventional industrial materials. These three options have been analysed in this text and compared with each other in terms of environmental impact.

Therefore, this text presents the application of this pilot project to the conservation of actual buildings (Option 1), subsequently developing environmental impact analyses. In addition, a parallel study was carried out showing the possible representation in identical conditions of the conservation of this house using the conventional industrial materials 
currently being used in other similar homes in the neighbourhood (Option 2; Figure 2). Finally, this comparison was extended to the supposed case of demolishing the house and rebuilding it with contemporary materials, another example found in the neighbourhood (Option 3; Figure 2). The full gamut of this study leads to interesting conclusions on the impact of the three options studied on society and the environment.

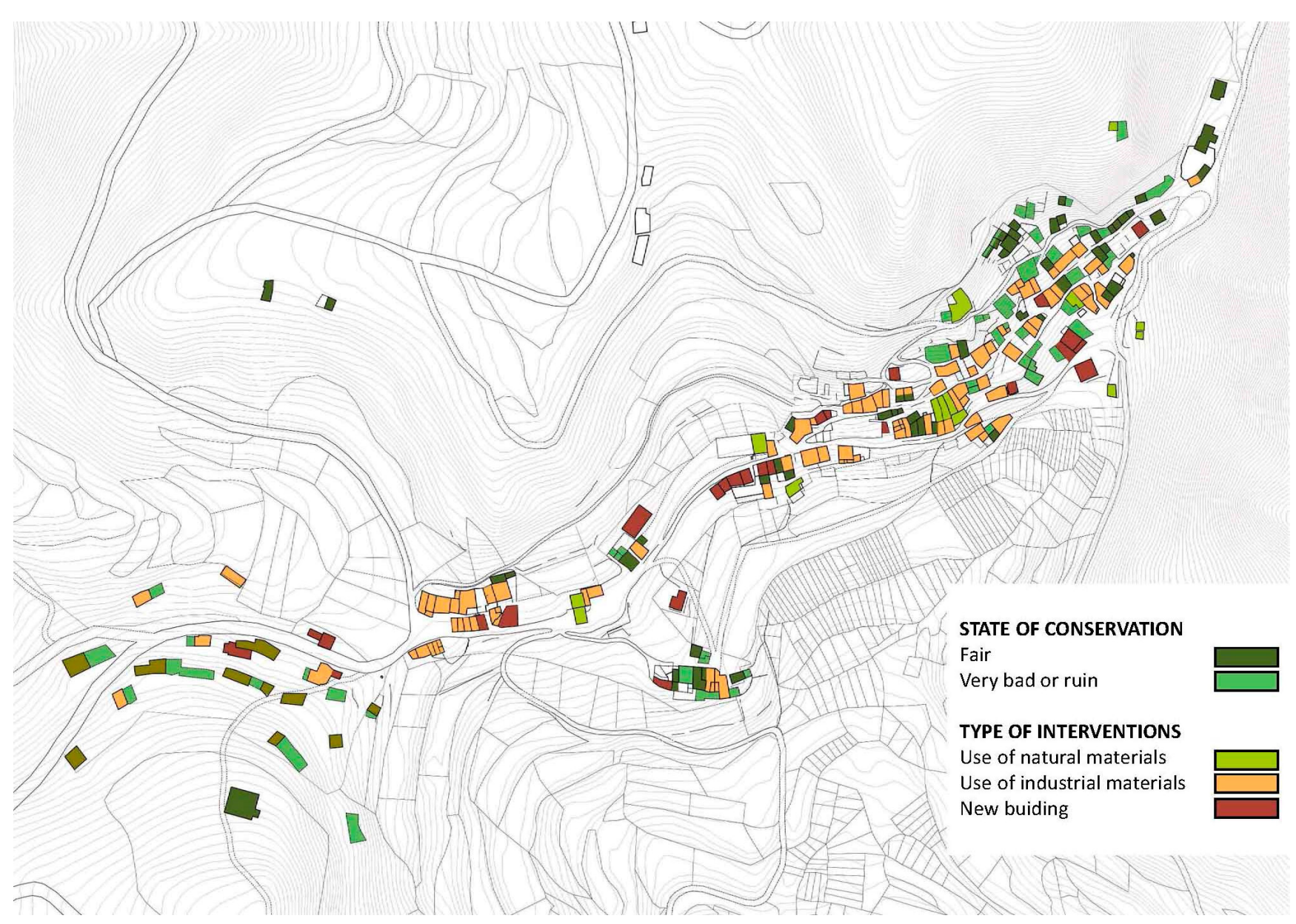

Figure 2. State of conservation and type of intervention done in the buildings at Sesga (Rincón de Ademuz, Valencia, Spain). Credits: C.M., F.V.

Applying a real case rather than carrying out an abstract simulation was felt to be more efficient. This decision prolonged the entire process, allowing the authors to obtain and handle accurate data in the field during an intense research along the years [43], and this made it possible to apply an informed approach to the conservation process.

The sustainability criteria applied in the conservation project phase for Option 1 were the result of observing common sustainability guidelines to this vernacular architecture, that is, following a philosophy of architectural conservation $[24,44]$ rather than basing these on quantitative criteria. The construction techniques and materials adopted in the refurbishment essentially sought physical, chemical, mechanical and material compatibility with the existing building. In any case, this philosophy for the conservation of vernacular architecture which has guided the project is in line not only with most of the qualitative sustainability parameters defined in the VerSus Programme [15], but also with most of the SDGs [45]. The quantitative measurement and LCA carried out at the end of the project and shown in this article have shown that the search for material respect and coherence in terms of the conservation of vernacular architecture also makes a significant contribution to environmental decarbonisation. 


\subsection{Case Study Description}

The traditional architecture of Rincón de Ademuz was born closely of its surroundings and adapts to its conditions, as is the case of vernacular architecture in general. The towns are clustered on the south-facing slopes to prevent the occupation of the arable land in the valley, and dwellings tend to be two or three storeys high, towering over the buildings immediately below but allowing lighting and ventilation [43]. The dwellings are generally built with masonry walls bonded with earthen mortar on the ground floor to prevent rising damp, while the upper floors are either thin, gypsum-rendered thin stone slab walls or sometimes rammed earth walls. However, the structure of the building is made up of gypsum structural pillars supporting rounded beams in juniper (Juniperus thurifera L.), pine (Pinus nigra, salzmannii) or poplar wood (Populus alba). Both the floors with gypsum-poured jack arch vaulting and the roof formed with reed and ceramic roof tiles placed with clay and straw mix are supported by these beams. Stone slabs and gypsum are used for dividing walls and built-in furniture inside the building [43].

As all these materials are proximity materials, originally barely any energy would have been spent on transporting them to the construction site [40]. In addition, many of the materials are used in the construction in their natural state, with almost no transformation, or with small transformations which also have a minimal impact on the environment, another lesson in sustainability to be learned from this vernacular architecture [40]. Finally, the philosophy of the vernacular architecture essentially builds and resolves its problems with the materials found locally. This is in itself a philosophy which allows us to save on resources and transport while allowing contemporary architecture to re-establish contact with an identity linked to surroundings, something which has been lost over the last hundred years $[7,8]$.

This vernacular architecture mostly uses gypsum as its only bonding agent, both because it is widely available in the surroundings and because it is five to seven times cheaper to calcine than lime in terms of fuel and time invested. This gypsum was manually calcined in the kilns near the towns and villages and mixed with a small amount of water to obtain a resistance capable of supporting up to four storeys [46].

Laboratory tests have confirmed these resistances, even using current commercial gypsum [47]. Equally, a hundred pillars analysed in the region have provided information on the rubble infill used in the gypsum concrete of the pillars, dispelling any suspicion that the stones may have been commonly bonded with gypsum [46]. Different accounts were also collected on the preference for the use of overcooked gypsum (anhydrite) in the construction of floors, given that this element was more waterproof.

The village of Sesga, where the restored dwelling is, and the dwelling itself answer to this description. The house (Figure 3 ) is three storeys high, with masonry enclosures on the ground floor and vertically placed stone slab walls on the upper floors. The pillars of the structure rise up from the masonry wall to form floors and roof with the help of pine and juniper beams and pine and poplar joists. Samples extracted from the beams have dated the construction of the original single-storey dwelling to circa 1732 [48]. The wall adjoining the neighbouring building, built with rammed earth, lies under this structure so that it is suspected that it could be a century older. In 1947, another storey was added to the dwelling and the adjoining volume was built over a pre-existing courtyard, using the traditional techniques previously described [49]. 

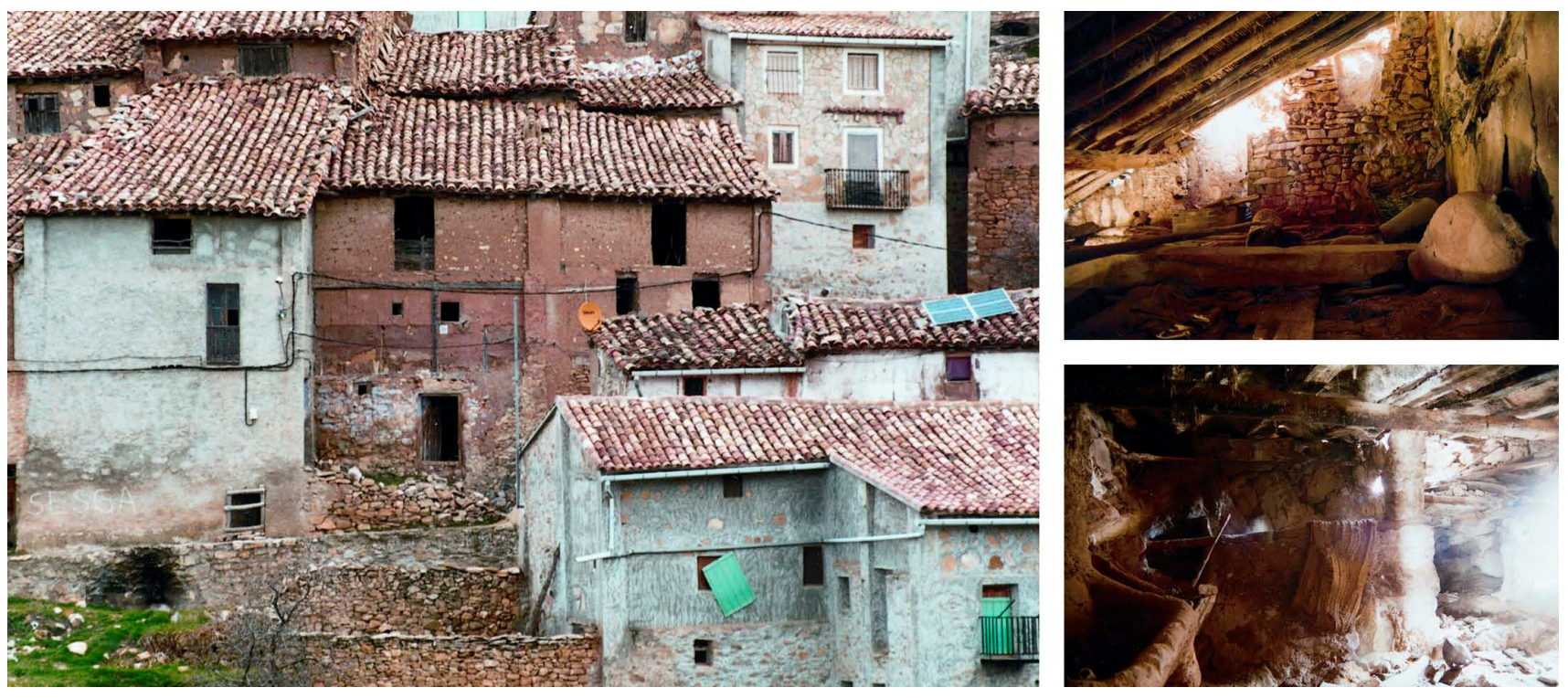

Figure 3. The house before the intervention. Credits: C.M., F.V.

This lengthy refurbishment of a vernacular dwelling using traditional construction materials and techniques which have been reinterpreted was proposed from the outset as an experiment, a pilot conservation action which could be visited in order to showcase the results to local residents and society in general. The three-century-old building was initially in an extremely poor condition (Figure 3) and at severe risk of collapse, with collapsed areas in the roof and flooring which let snow through to the ground floor [50].

\subsection{Criteria Used for Decision Making}

The refurbishment mostly employed natural materials including gypsum, lime, wood, reed, cork, etc. The structural reinforcement used local timber to replace beams and braces that had rotted away or to build the joinery missing from the house; local timber and natural glues were used in the restoration of the doors and the joinery found in the house; reeds were used to reinforce the gypsum and to form the basis of the roof; lime was used to consolidate and grout the rammed earth wall; gypsum was used for the repair or reconstruction of some collapsed small vaults and to build compression layers reinforced with reed meshes or twine [50,51]. Gypsum rendering was reinforced with twine. Lime mortar was used to rejoint any masonry walls requiring structural reinforcement and for the ground floor flooring. Clay and straw were used to place the tiles recovered on the roof. Pressed cork panels were used for the thermal insulation of the walls and local-made brick was used as secondary wall to better insulate enclosures and to build new interior partition walls. Other less important materials were used following the same type of priority [43,50].

After the structural strengthening, the aim of intervention was to update contemporary habitability standards while preserving the vernacular nature of the building as much as possible, respecting its handcrafted finishes, the outlines of its construction, as well as the textures, qualities and patina of its materials. At the same time, efforts have been made from the outset to remain as much in line as possible with the sustainability parameters observed in vernacular architecture and coded in the VerSus Programme [15], with the SDGs [45] and with the traditional life cycle of the materials usually used in the local vernacular architecture.

The specific actions carried out were:

- Historic finishes have been respected. Any existing bare rough stone or stone slab walls have been maintained and any existing gaps have been jointed. 
- Interior gypsum-rendered walls have been re-rendered after adding thermal insulation and new walls. Extremely fast-setting gypsum was used as rendering, following tradition and leaving the natural marks of the trowel.

- Flooring had a waxed gypsum rendering, recovering an almost-extinct local tradition.

- Double-glazed wooden windows were added where previously there had only been wooden shutters.

- The inner doors of the dwelling are small historic doors which have been repaired, including a charm against evil spirits in the form of three candle burn marks. The low doors make it necessary to duck when entering the room, as if revering the history of the space.

The refurbished vernacular house shows off the beams and the construction of its floors, ceilings and reed roof (Figure 4). The exterior façade, with a stone masonry plinth on the ground floor and rendered in reddish gypsum on the upper floors, conserves the same appearance and finish as before the intervention (Figure 4). Behind a façade, which still preserves the vernacular appearance of three centuries ago, there is a house with all the characteristic standards and installation of a contemporary dwelling but largely preserving its character. This has set a precedent with a clear message, especially for local residents: it is possible to preserve ancestral material culture while also carrying out the refurbishment of homes to be used in the present.
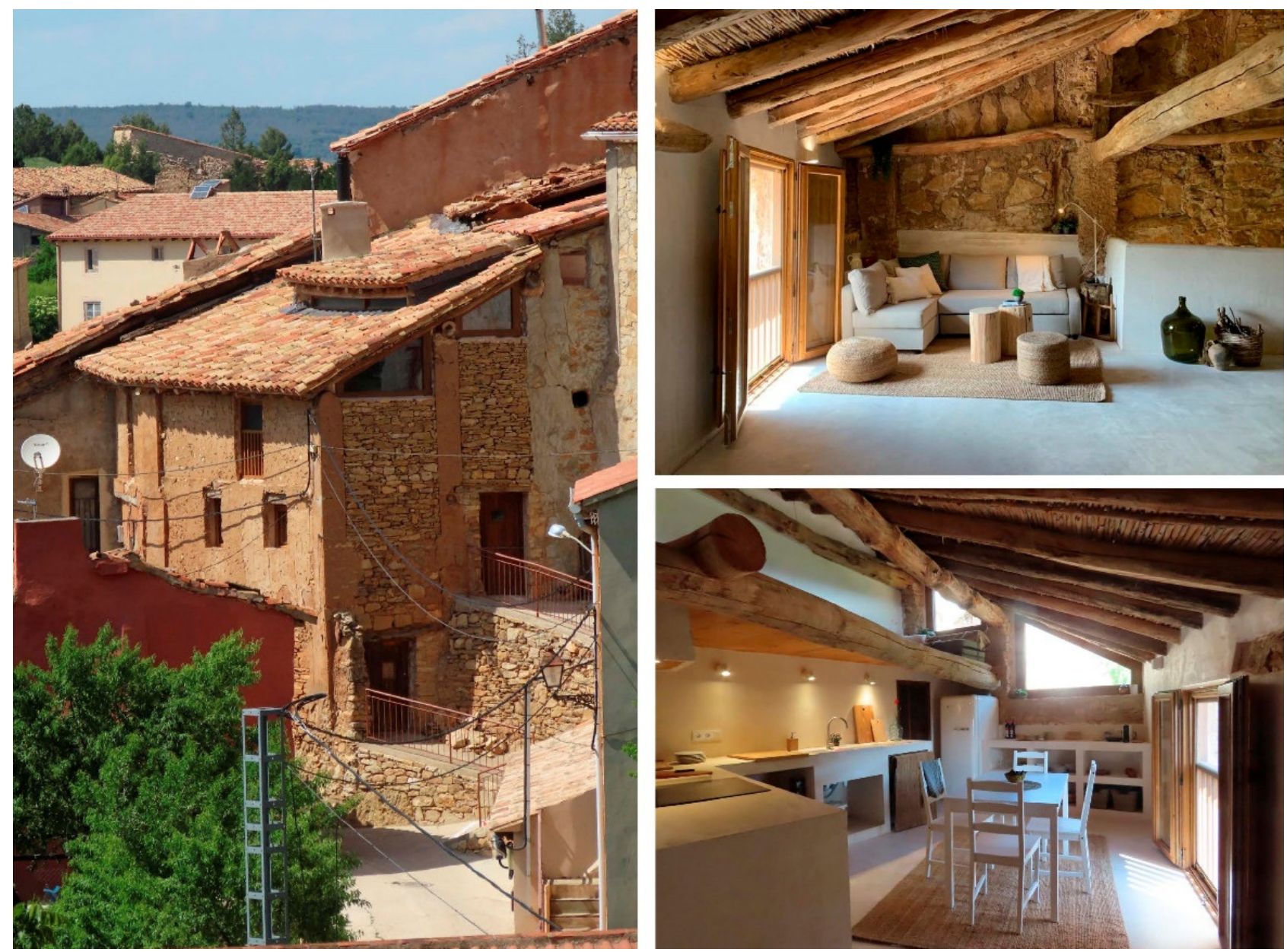

Figure 4. State of the house after refurbishment of its external facades and internal spaces. Credits: C.M., F.V. 


\subsection{Evaluation Tools Used for Sustainability Integration in the Design Process of a Building Refurbishment Projects}

The refurbishment has followed qualitative and quantitative approaches to integrate the sustainability in the design of the refurbishment process.

\subsubsection{VerSus Methodology and SDGs}

The qualitative criteria were based on the use of VerSus methodology [16], which includes the fifteen principles (Figure 5) each in turn broken down into eight parameters [16]. The application of these 15 principles and respective parameters to the case of study evidences how this pilot refurbishment helps to reduce pollution and waste materials, and contributes to health quality since it is built with natural low-carbon footprint materials and is in a suitable location. It also follows the principles of sociocultural sustainability as it protects the cultural landscape by preserving the building in its original condition, while enabling the transmission of construction traditions, promoting coordination and social cohesion between craftsmen taking part, and contributing to the economic autonomy of this depopulated location. It also follows the principles of socioeconomic sustainability by promoting local work, providing savings in resources and optimisation of efforts and extending the lifespan of the building.

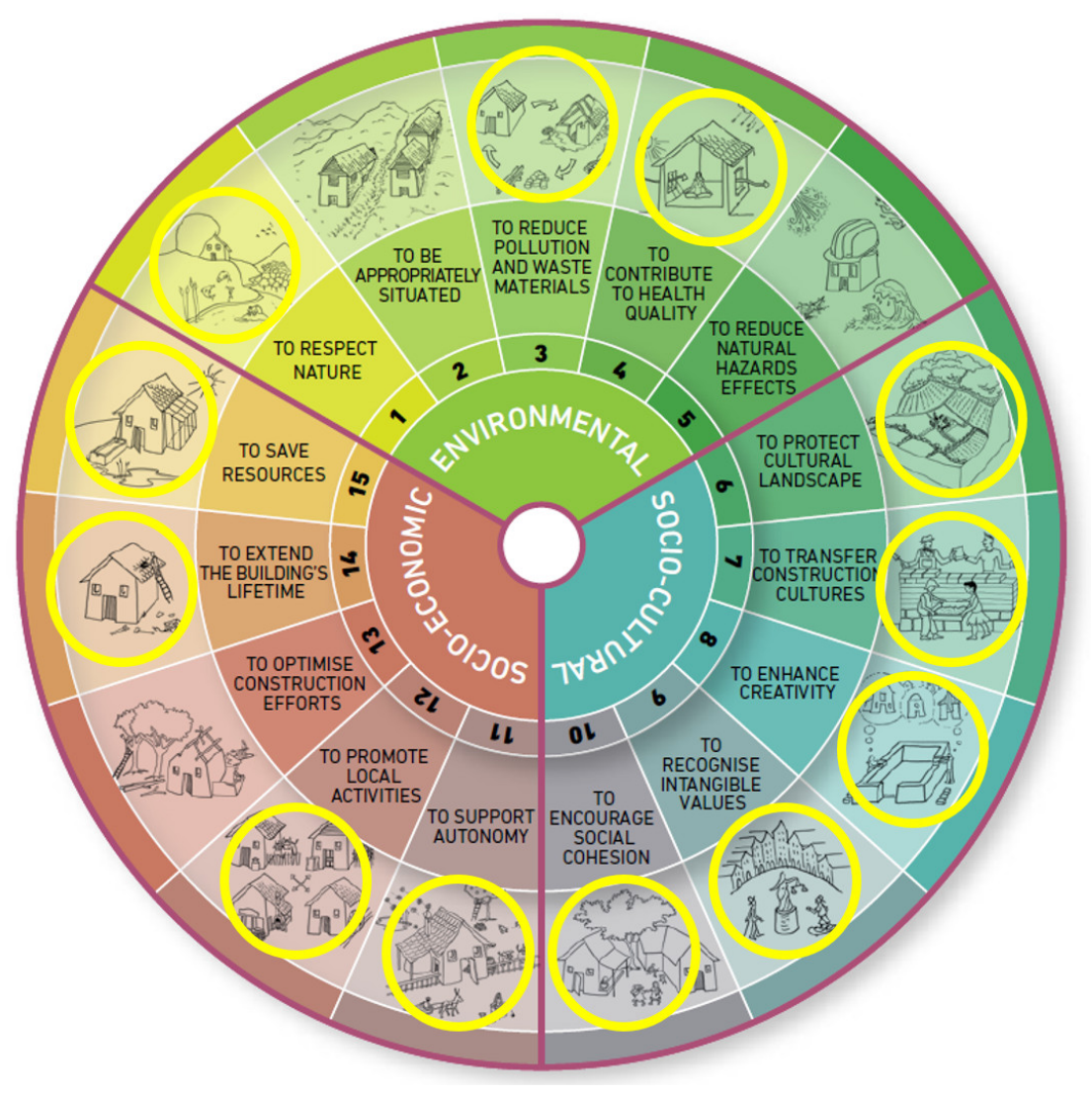

Figure 5. Application of the Versus method to the case study. Credits: [15] modified by authors.

In addition, efforts have been made to apply the philosophy of the SDGs, particularly the fight against poverty and contribution to the economic development of inland rural communities, using local labour and construction materials and techniques, promoting salubriousness, water purity and local natural life. Climate action is also taken through the predominant use of non-polluting natural proximity materials to avoid transport, taking advantage of the sun as a primary source of heat respecting the historic structure of the openings of the house and exercising responsible consumption and production by mostly reusing existing materials to repair the dwelling. 


\subsubsection{Life Cycle Assessment Integration in the Design Process of a Refurbishment}

The authors aim to compare the LCA results of the refurbishment project of the single-family house using natural materials with a standard or usual refurbishment in the area using conventional industrial materials, and with an equivalent newly constructed building on the same plot. The LCA followed the four stages: (1) Goal and scope, (2) Life Cycle Inventory, (3) Life Cycle Impact Assessment and (4) Interpretation in compliance with the LCA standards ISO 14040 [52], ISO 14044 [53] and the EN 15978 [54] (building LCA), and the EN 15804 [55] (construction product LCA). The functional unit was the complete building since the study aims to compare the total impacts of different material alternatives of a refurbishment project. The building service life was assumed as 50 years (according to CTE [56]). This study focuses on comparing the embodied impacts produced by the building materials during its life cycle. Figure 6 shows the modules considered in the assessment.

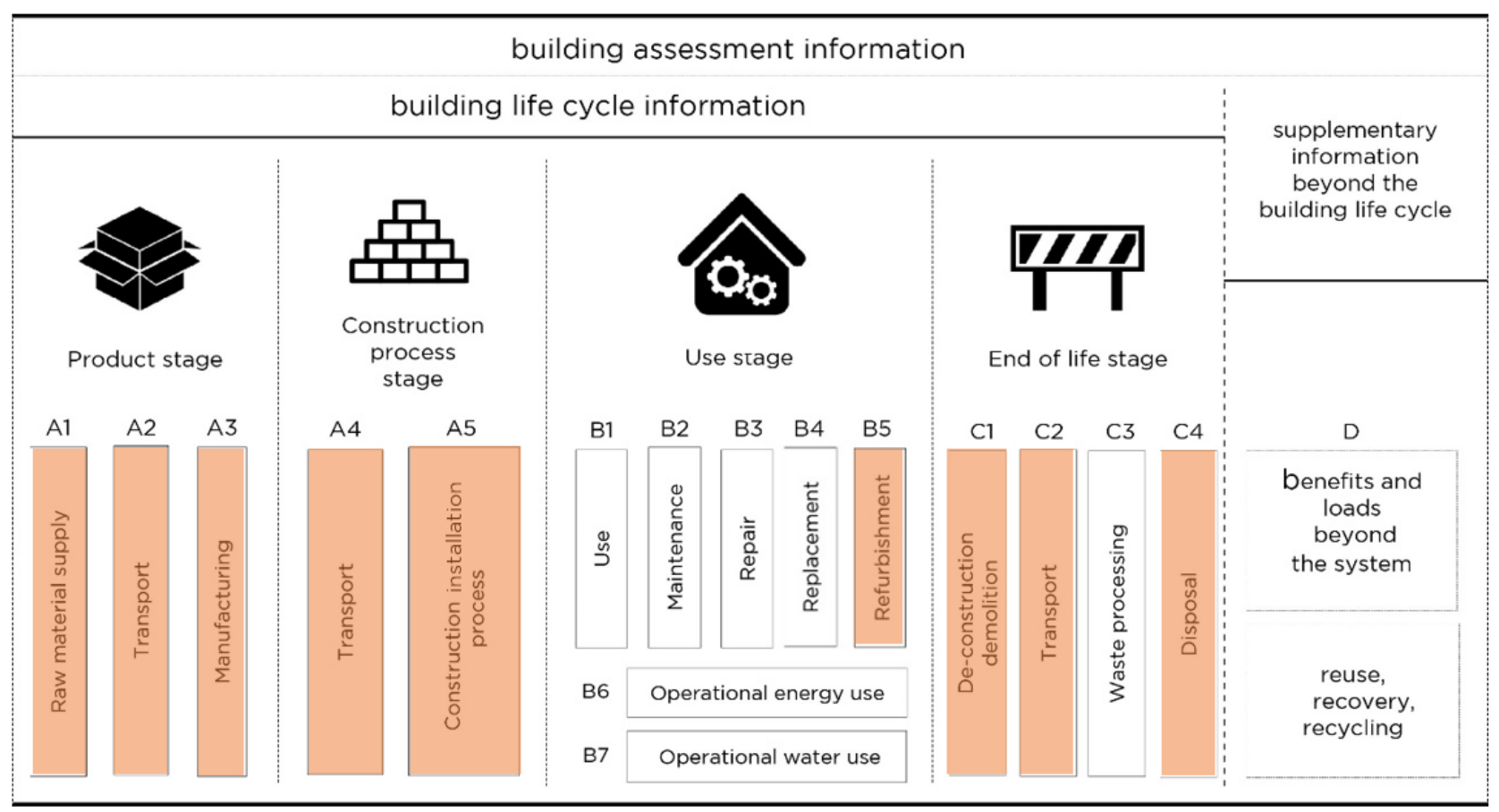

Figure 6. Life Cycle Assessment Information Modules EN 15978 [54] included in this study.

\section{Options Assessed}

To quantify the advantages of the natural design option of the refurbishment project and demonstrate the benefits achieved by using the VerSus methodology, the LCA compared three options:

- Option (1) a refurbished building with natural materials, defined as those materials that wholly or partly are derived from biomass, such as plants, trees or animals [57] (e.g., wood, reed, gypsum, cork, earth, lime, etc.)

- Option (2) a refurbished building with conventional industrial materials, defined as those materials that are the most representative and often used currently on a site (e.g., bricks, concrete, steel, polystyrene, etc.)

- Option (3) the new building construction with conventional industrial materials together with the complete demolition of the existing building.

Goal, Scope and System Boundaries Definition

Figures 7 and 8 illustrate the LCA Information Modules included in the LCA for each option compared. This LCA modularity organisation of the refurbished building is based on 
the study conducted by Frey et al. [58], and collected by Hasik et al. [59] as a methodological approach to compare the benefit of renovation/refurbishment vs. new construction.

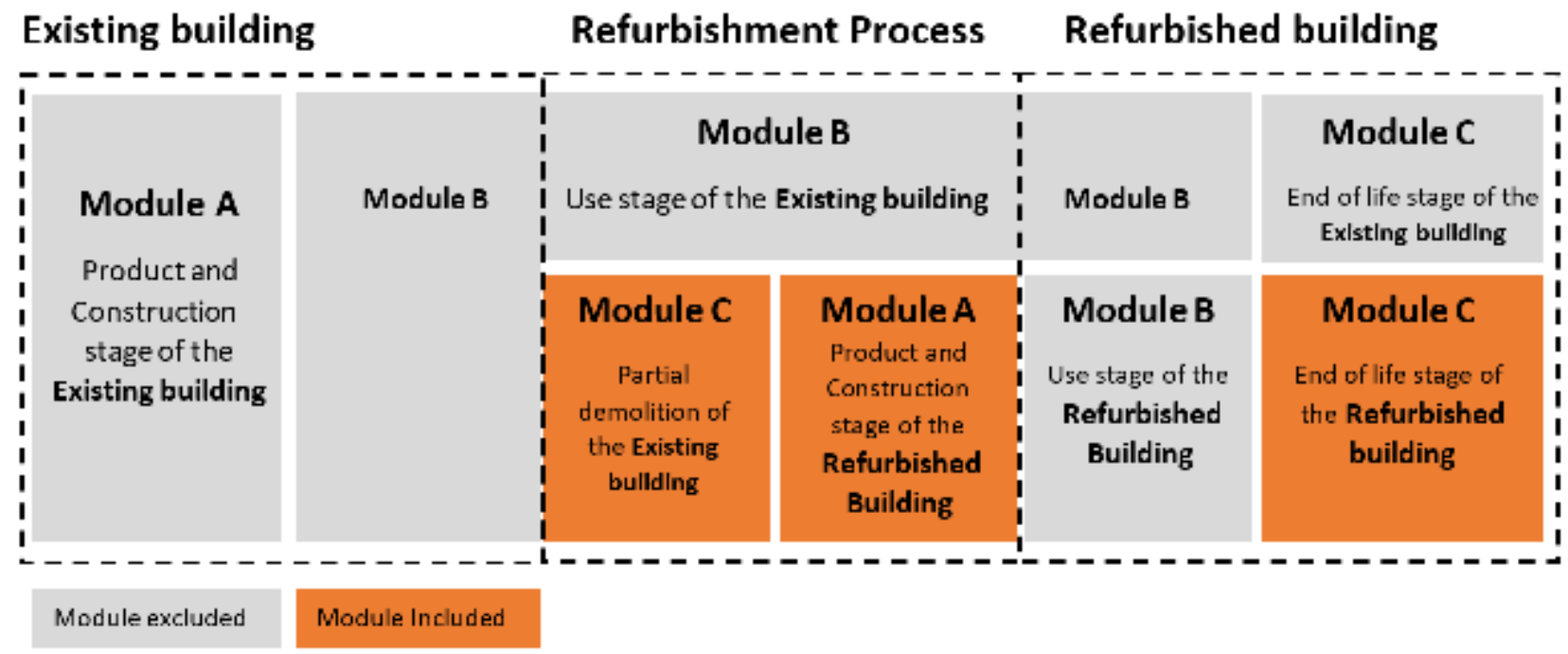

Figure 7. Life cycle assessment information modules included EN 15978 [54] in the study Options 1 and 2. Source inspired in $[58,59]$.

Existing building

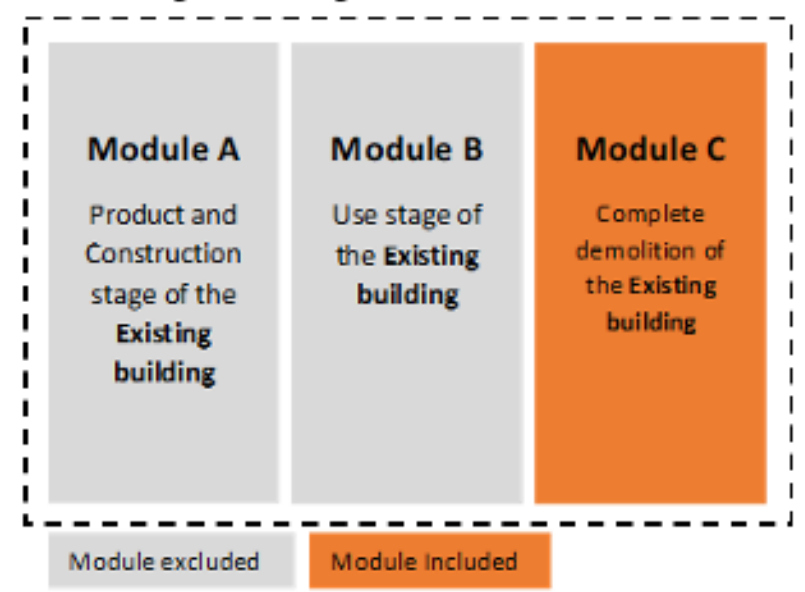

\section{New Building}

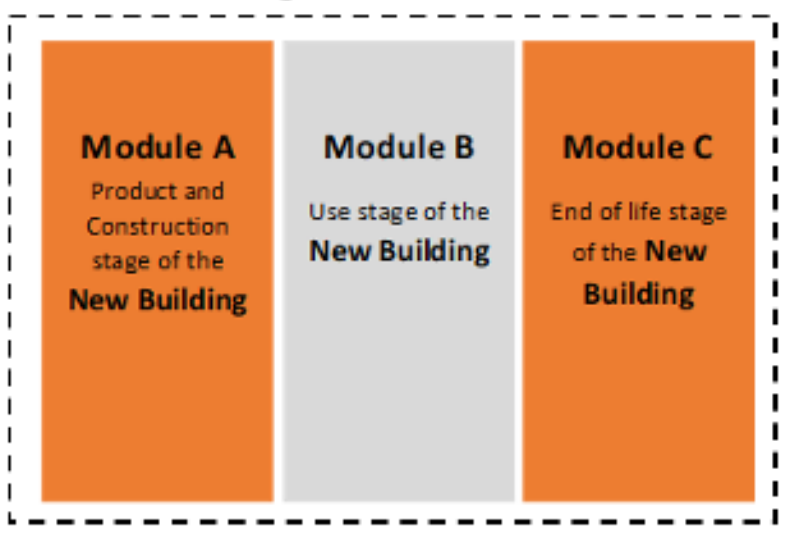

Figure 8. Life cycle assessment information modules EN 15978 [54] included in the study Option $3 . \quad$ Source inspired in $[58,59]$.

When considering the LCA of refurbishment process several particularities arise. One of them is the difficulty/complexity in obtaining information related to the existing building to conduct a complete LCA following the current standards (see Figure 6). Thus, the present study focused the LCA of the refurbishment process in calculating:

1. The impacts of both the small demolition in Options 1 and 2 and the initial total demolition in Option 3, transport, and final disposal of the existing building (Module C including C1, C2, C4; see Figures 7 and 8).

2. The impacts of the product and construction stages (Module A including A1, A2, A3, A4 and A5) of the refurbishment processes in Options 1 and 2 (see Figure 7), and of the new building in Option 3 (see Figure 8).

3. The impacts of the final total demolition, transport and final disposal of the building (Module C including C1, C2, C4) in Options 1 and 2 (see Figure 7) and in Option 3 (see Figure 8). 


\section{Life Cycle Inventory}

The building inventory included a collection of the main materials used during the building construction process. The LCA calculation was conducted in Excel and the environmental data used for the assessment was the ecoinvent database v 1.2 [60]. During the LCA, several simplifications and assumptions were developed such as the adaptation of the list of material to the ecoinvent v1.2 dataset [60]. Table 1 includes the correspondence of both lists (further information: Tables S1 and S2).

Table 1. List of materials and inventory assumptions (refurbishment natural materials).

\begin{tabular}{|c|c|c|c|}
\hline \multicolumn{2}{|c|}{ Option 1} & \multicolumn{2}{|c|}{ Options 2 and 3} \\
\hline Listed Material & $\begin{array}{l}\text { Adapted Materials to the } \\
\text { Ecoinvent v1.2 Dataset [60] }\end{array}$ & Listed Material & $\begin{array}{l}\text { Adapted Materials to the } \\
\text { Ecoinvent v1.2 Dataset [60] }\end{array}$ \\
\hline Stone & Basalt & Aluminium & Aluminium \\
\hline FEL'X & Bitumen & Brick & Brick \\
\hline Brick & Brick & Cement & Cement \\
\hline Cement & Cement & Ceramic Tile & Ceramic tile \\
\hline Ceramic tile & Ceramic tile & Demolition (pre-construction) & Inert material \\
\hline Cork & Cork & Glass & Glass \\
\hline Demolition (pre-construction) & Inert material & Gravel & Gravel \\
\hline Glass & Glass & Gypsum & Gypsum \\
\hline Gravel & Gravel & EPDM & Polyethylene \\
\hline Gypsum & Gypsum & Polystyrene & Polystyrene \\
\hline Limestone & Limestone & Sand & Sand \\
\hline Cane & Log (cane) & Metal & Steel \\
\hline EPDM & Polyethylene & Wood & Wood \\
\hline Polystyrene & Polystyrene & & \\
\hline Sand & Sand & & \\
\hline Metal & Steel & & \\
\hline Straw & Straw & & \\
\hline Wood & Wood & & \\
\hline \multirow{4}{*}{$\begin{array}{l}\text { Rammed earth (composition } \\
\text { based on [61], sand, } 61.3 \% \text {, Clay } \\
34.4 \% \text {, Straw } 0.44 \% \text {, Lime } 3.7 \% \text { ) }\end{array}$} & Straw & & \\
\hline & Lime & & \\
\hline & Clay & & \\
\hline & Sand (wall) & & \\
\hline
\end{tabular}

Other assumptions were:

1. For modelling the transports, regardless the type of material a unique dataset was considered, "transport, lorry 16t", and the distances to the manufacturing points were estimated based on the real scenario.

2. During the construction stages, the energy consumption of machinery and the impact of construction waste were considered (estimated as a $5 \%$ of the amount of each material).

3. The calculation of the energy and fuel consumption was based on ecoinvent data v1.2.0 [60].

4. The assumed end-of-life scenarios were $100 \%$ incineration for the natural materials and $100 \%$ landfill for the rest of building materials in all the assessed options.

5. The distances to the landfill and incineration point for final disposal were $40 \mathrm{~km}$.

Life Cycle Impact Assessment

The LCIA was developed by using the CML 2001 method [61] and included the following impact categories: acidification potential (AP in $\mathrm{kg} \mathrm{SO}_{2}-\mathrm{Eq}$ ), climate change (GWP in $\mathrm{kg} \mathrm{CO}_{2}-\mathrm{Eq}$ ), eutrophication potential (EP in $\mathrm{kg} \mathrm{PO}_{4}^{-3}-\mathrm{Eq}$ ), freshwater aquatic ecotoxicity, (FAETP in kg 1,4-DCB-Eq), human toxicity (HTP in kg 1,4-DCB-Eq) and stratospheric 
ozone depletion (SODP in kg CFC-11-Eq). The approach to include the biogenic carbon was the so-called (approach -1/+1 [62]) based on EN 16449 [63]. The followed approach was based the account of biogenic carbon on the principles provided by [64]. It assumed that during biomass growth, an uptake of carbon $(C)$ from the atmosphere through photosynthesis ( $C$ uptake) is temporarily stored in wood-based products (biogenic C storage), (see Figure 9). Then, as the end-of-life scenario is considered as $100 \%$ incineration (for natural materials), the biogenic carbon (a) is completely emitted to the atmosphere [64].

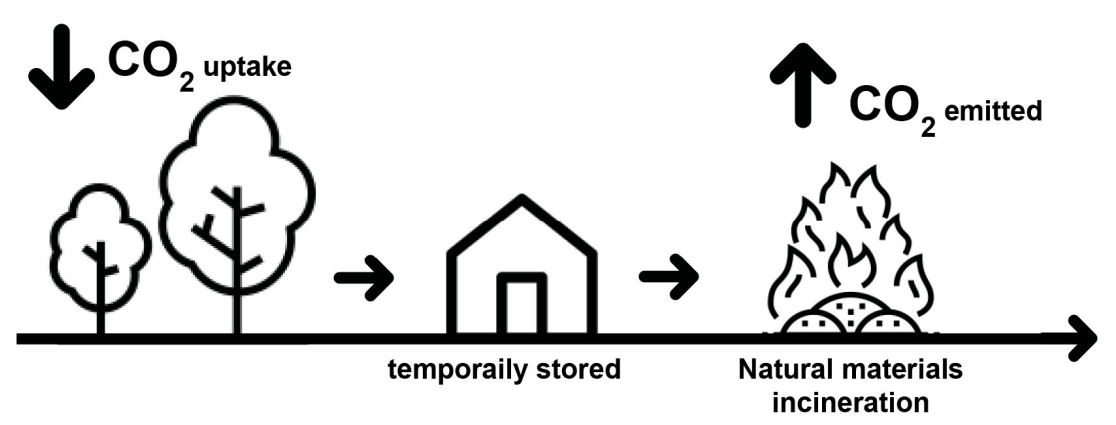

Figure 9. Schematic diagram of carbon storage and delayed emissions of the temporary stored carbon for a wood-product incineration end-of-life scenario. (Source inspired in [64]).

\section{Results}

\subsection{Application of Qualitative Criteria (versus Program and SDGs)}

This conservation work was devised to include as much manual labour, including specialists, as possible, while the use of materials and machinery is proportionally reduced in relative terms. As this manual labour was local, it benefited the local economy while promoting and ensuring the continuity of local trades and artisans, encouraging the population to stay in an inland area with endemic depopulation and limited employment opportunities. In the construction of a new building, the maximum use of manual labour usually accounts for 30\% of the cost [65]. This conservation has been devised for manual labour to represent approximately $50 \%$ of the total cost of the project [65]

In addition, over $60 \%$ of the conservation materials in terms of weight are locally sourced, either from immediate surroundings or from the same province (see Supplementary Material: Tables S4-S6). This has meant that the work has also contributed to local economic development, extracting raw materials and manufacturing products in nearby workshops and industries, something which in turn has usually lowered $\mathrm{CO}_{2}$ emissions due to transport.

Furthermore, the use of traditional materials and techniques and the reinterpretation of their systems for this conservation work have helped highlight the vernacular identity of this sort of construction, enabling the population to value the past, material culture and architectural heritage of simple dwellings and settlements, traditionally synonymous with the poverty of yesteryear, to be eliminated or cancelled for the sake of progress.

The conservation work took several years in the form of an experimental site (more than 20 workshops, each one with 20 students coming from different countries), and specialised visits have taken place. It is estimated that in these years more than 600 people may have visited the site, including students, teachers and professionals. It has become a point of reference for the other residents of the village, province and beyond (visits are organised every weekend to show the restored buildings). Moreover, the local government commissioned the authors of this refurbishment a manual with guidelines for the refurbishment of buildings in the area resorting to local materials and techniques [66].

The cost of refurbishment (Option 1) was compared with that of the equivalent new construction (Option 3), showing the lower cost of the intervention and its affordability in absolute terms [67]. Furthermore, the convenience of having used proximity materials and the percentage of the total cost of the refurbishment which accounts for manual labour have been deepened. The manual labour in this refurbishment (Option 1) increases by 70\% 
in relative terms compared with the manual labour in the new construction (Option 3), while proportionally reducing the percentage of machinery and materials [65]. These two factors encourage inclusiveness and directly benefit the workers, artisans, trades and local production workshops, especially in these economically deprived depopulated inland regions.

\subsection{Application of Quantitative Criteria ( $L C A$ )}

Figure 10 shows the environmental impacts obtained for each of the options described in Section of Options Assessed. The LCA results provide evidence that the Option 1 is the best alternative since it is the one that has the least impact in all the categories. The use of natural materials for the refurbishment project (Option 1) achieves $50-80 \%$ reduction in the environmental impacts, i.e., more than $50 \%$ compared with the renovation with conventional industrial materials (Option 2) and more than 70\% compared with the new building also with conventional industrial materials (Option 3).
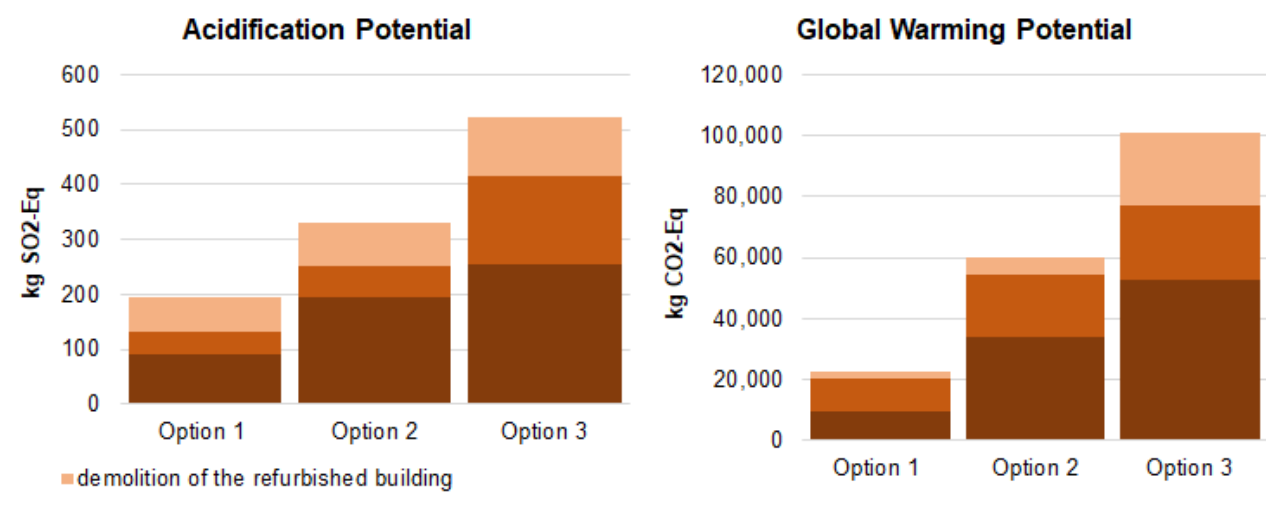

- small demolition/demolition at the existing building

mproduct and construction of the refurbished building
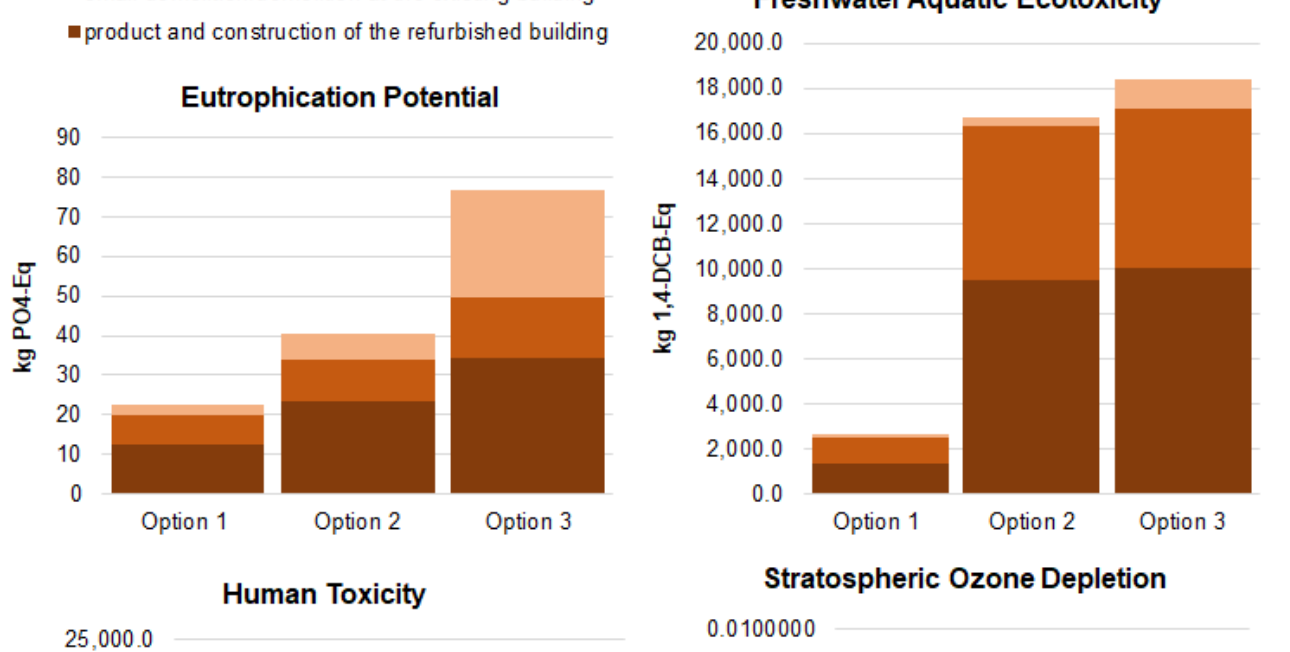

\section{Stratospheric Ozone Depletion}
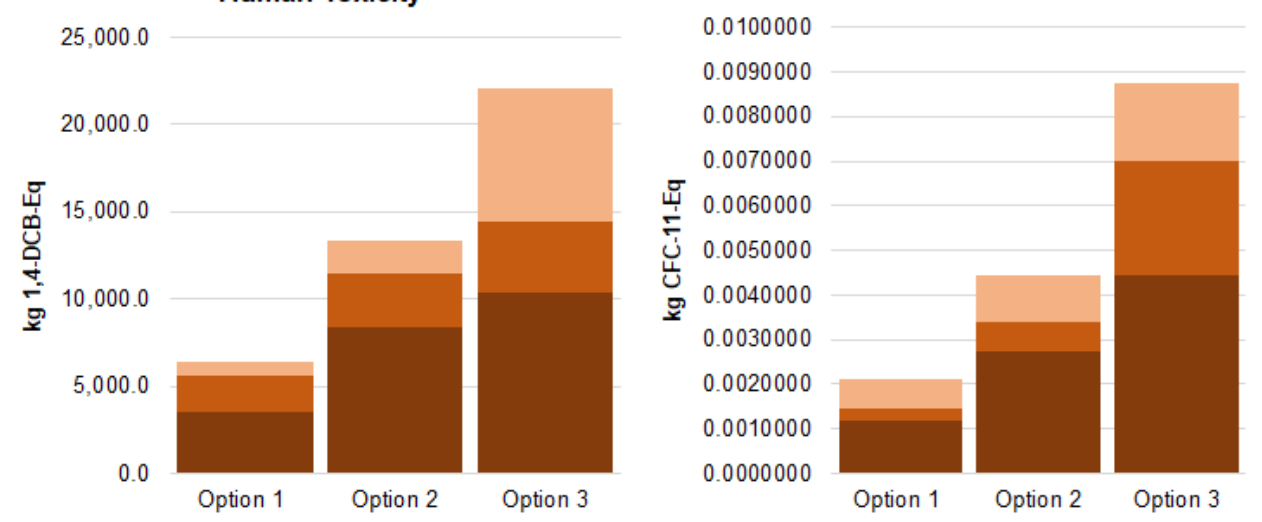

Figure 10. LCA results of the case study application. 
Option 1 produces less than $50 \%$ of the impact caused by the Option 3 in all the assessed categories. The impacts related to the product and construction stage were the highest in each assessed impact category and option assessed, which highlights the relevance of the selected materials in the design stage.

However, in the GWP category the impacts of the product and construction stages were similar to the impact of the demolition of the refurbished building. This can be explained due to the use of natural materials, and the assumed scenario related to the storage and emission of the biogenic carbon (see Figure 4). The use of natural materials at the product and construction stages reduced more than $80 \%$ of the environmental impacts compared with Option 3 in all the impact categories assessed. Moreover, the use of local materials at the construction stage leads to a reduction of $70 \%$ of the environmental impacts compared with Option 3 in all the impact categories assessed. The complete calculation and the list of the dataset are included in the supplementary data file (see Table S3 for calculations, and Tables S7-S9 for the summary of results).

\section{Discussion}

The results obtained provide evidence that the qualitative criteria (VerSus) used to include sustainable principles in the design process of the refurbishment project are supported by the lower values in the quantitative assessment (LCA).

The refurbishment of this simple vernacular single-family house shows that it is not necessary to invent new building techniques, materials and processes; a contemporary approach reinterpreting the vernacular techniques and materials suffices to meet all objectives at once: mitigating climate change as seen from the LCA is carried out; this co-creation process involves the architect, owner and master builder, but also history, tradition, material culture and the idiosyncrasy of local materials. For example, the process of reinforcement of floors and roof incorporated a gypsum compression layer which was reinforced with locally sourced natural fibres (straw, wool, hemp, reed, etc.). Samples were extracted from all these and tested in laboratories to decide which combination offered the best results, subsequently using it on site. Materials were all local and traditional, with a low carbon footprint, although the execution was contemporary. The structural properties of the reinforced floor were on a par with those of a floor built or reinforced with cement-reinforced concrete.

This all shows the potential of refurbishment using natural materials over refurbishment using conventional industrial materials or over a new construction following demolition of the existing dwelling. The application of these principles in the field of construction could significantly affect SDGs and related environmental, sociocultural and socioeconomic aspects, as well as helping to reduce the environmental impact of new construction.

\section{Detected Challenges and Limitations}

The LCA application focused on quantifying the environmental impacts produced by the building; other aspects regarding economic and social dimensions can be addressed by using this approach. The LCSA (Life Cycle Sustainability Assessment) can be also a suitable approach to evaluate in a quantitative way the impact and benefits that a certain building can produce. Regarding the LCA calculation, several assumptions and simplifications were done, mainly due to the lack of specific data.

The study also demonstrates the benefits of using natural materials instead of conventional industrial ones; however, in practice, the massive use of this type of materials is still far from being extended. Thus, in the future other studies can be focused on integrating other variables in the assessment to better understand the barriers and opportunities to extend its use in other type of buildings and at different scales.

This application would also entail other associated challenges such as the renewed use of natural materials and the trades versed in construction techniques. A higher percentage is allocated to labour than to the use of materials and machinery, although the final cost remains the same, with an equal contribution toward reactivating the economy. 


\section{Conclusions}

The results obtained also provide evidence of the potential environmental advantages that vernacular techniques and natural materials have in the context of Valencia (Sesga), which have not been explored before. In short, it is demonstrated that vernacular construction can be developed as a contemporary option for housing in this region.

The refurbishment work of Sesga single-family houses based on natural materials has been demonstrated as the best solution to reduce the environmental impacts of building construction in this region, compared with the use of conventional industrial materials either in refurbishments or in new buildings, that are the two most common options not only in the village, but also in the whole region. Moreover, the study demonstrates that the combination of qualitative (VerSus) and quantitative (LCA) criteria can help to reduce the environmental impacts and integrate sustainability criteria in the design process. Furthermore, this refurbishment resorted to the use of traditional materials and techniques and the reinterpretation of their systems for the structural strengthening of walls, floors and ceilings, as well as final finishes. For example, based on the knowledge of traditional gypsum and its analysis in specialist laboratories [51], systems were created for the strengthening of floors and ceilings using gypsum compression layers reinforced with reed or hemp string, among other natural fibres used in experiments both on-site and in the laboratory. There were also reinforced renderings of the same type with fibres to prevent bulged walls from collapsing. Following older local builders, gypsum samples tested in the laboratory displayed the same or even greater resistance than a current reinforced concrete structure [51]. This use of gypsum and natural fibres conceived as contemporary reinforcements seeks the same physical-chemical-mechanical compatibility as that of a human organ transplant, as the same phenomenon of rejection of the implanted organ could be generated in the refurbished building. However, several limitations in the assessment and integration of qualitative aspects in the design process are detected. Qualitative methods demonstrated the economic and social benefits of using these techniques. However, the life cycle perspective still remains scarce. Nevertheless, it should be noted that the materials traditionally used in these houses built more than two centuries ago have reached the present day, so it does not seem unreasonable to hypothesise that the same materials used today could last at least as long. Thus, the integration of other quantitative aspects in the design process can be a future topic to be addressed.

This study has value in the specific context of the village of Sesga and the county of Rincón de Ademuz, but it also has a wide possibility of application in similar contexts in Spain and other European countries [68]. Spain is currently one of the European countries that suffers most from depopulation of rural areas, with $52 \%$ of the population living in cities of more than 50,000 inhabitants, while only $3.2 \%$ live in municipalities with less than 1000 inhabitants [69], a phenomenon currently called "Emptied Spain" [70]. In the rest of Europe this same phenomenon has been worsening in several rural areas, especially in Italy, Portugal, Greece and Germany, concerning the European Union [69], at the same time that it is trying to reduce $\mathrm{CO}_{2}$ emissions [1,2]. In this context, the renovation of homes with natural materials meets several objectives: showing the possibility of respecting and preserving a vernacular building as part of history and identity and updating it for contemporary life; using natural materials that are extracted and worked locally by creating work opportunities for local trades; helping to promote local activities and to fix the population in rural areas; and lastly, reducing $\mathrm{CO}_{2}$ emissions. 
Supplementary Materials: The following are available online at https:/ / www.mdpi.com/article/10.3 390/su13179800/s1, Table S1: Materials and unit process inventory; Table S2: List of materials and inventory assumptions (refurbishment with conventional industrial materials and new building with conventional industrial materials); Table S3: complete calculations (excel file); Table S4: Materials employed in the Option 1 "Refurbishment with natural materials" used for the LCA calculations; Table S5: Materials employed in the Option 2 "Renovation with conventional industrial materials" used for the LCA calculations; Table S6: Materials employed in the Option 3 "New building with conventional industrial materials" used for the LCA calculations; Table S7: Impacts on Option 1: Refurbishment with natural materials; Table S9: Impacts on Option 3: Complete substitution of the existing building by a new construction.

Author Contributions: F.V. and C.M. have developed the refurbishment project and directed the conservation works on site, as well as made the calculations on the percentage of the costs attributed to manpower, machinery and materials and collected the provenance data of the materials used. They have supported the conceptualisation of the article. B.S.-V. and C.L. have developed the Life Cycle Assessment. All authors have contributed to the definition of the article's methodology and the revision of the text. All authors have read and agreed to the published version of the manuscript.

Funding: This research was partially funded by the project "Versus+/Heritage for People", co-funded by the European Commission as part of the Creative Europe Culture Programme (Ref. 607593-CREA1-2019-1-ES-CULT-COOP1) for the period 2019-2023; and the research project "Earthen architecture in the Iberian Peninsula: study of natural, social and anthropic risks and strategies to improve resilience" Risk-Terra (ref. RTI2018-095302-B-I00; main researchers: Camilla Mileto y Fernando Vegas), funded by the Spanish Ministry of Science, Innovation and University.

Institutional Review Board Statement: Not applicable.

Informed Consent Statement: Not applicable.

Data Availability Statement: Not applicable.

Acknowledgments: The authors wish to thank the quantity surveyor Salvador Tomás Márquez for his help during the construction process and costs calculations.

Conflicts of Interest: The authors declare no conflict of interest.

\section{References}

1. Von der Leyen, U. A Union That Strives for More. My Agenda for Europe. Available online: https://ec.europa.eu/info/strategy/ priorities-2019-2024_es\#documents (accessed on 3 June 2021).

2. European Commission. Communication from the Commission to the European Parliament, the European Council, the Council, the European Economic and Social Committee and the Committee of the Regions, the European Green Deal, COM (2019), 640 Final; European Commission: Brussels, Belgium, 2019.

3. Jensen, P.A.; Maslesa, E. Value based building renovation-A tool for decision-making and evaluation. Build. Environ. 2015, 92, 1-9. [CrossRef]

4. European Commission. Commission Staff Working Document, Sustainable Products in a Circular Economy-Towards an EU Product Policy Framework Contributing to the Circular Economy, SWD (2019) 91 Final; European Commission: Brussels, Belgium, 2019.

5. Council of Europe. Council of Europe Framework Convention on the Value of Cultural Heritage for Society. 2005. Available online: https: / / rm.coe.int/1680083746 (accessed on 5 June 2021).

6. Ballester, J.M. Vernacular architecture in the modern concept of cultural heritage. In Vernacular Architecture: Towards a Sustainable Future; Taylor and Francis: London, UK, 2015; pp. 3-8.

7. Oliver, P. Dwellings: The Vernacular House World Wide; Phaidon: New York, NY, USA, 2003.

8. Oliver, P. Built to Meet Needs. Cultural Issues in Vernacular Architecture; Elsevier: Amsterdam, The Netherlands, 2006.

9. Frey, P. Learning from Vernacular; Actes Sud.: Arles, France, 2010.

10. Weber, W.; Yannas, S. (Eds.) Lessons from Vernacular Architecture; Routledge: Glasgow, UK, 2014.

11. Vellinga, M. Vernacular architecture and sustainability: Two or three lessons ... In Vernacular Architecture: Towards a Sustainable Future; Taylor and Francis: Boca Raton, FL, USA, 2015; pp. 3-8.

12. Vellinga, M. The noble vernacular. J. Archit. 2013, 18, 570-590. [CrossRef]

13. Neila, F.J. Miradas Bioclimáticas a la Arquitectura Popular del Mundo; García-Maroto Editores S.L.: Madrid, Spain, 2015.

14. Neila, F.J. La Arquitectura Vernácula Más Sostenible; García-Maroto Editores S.L.: Madrid, Spain, 2017.

15. Guillaud, H.; Moriset, S.; Sánchez, N.; Sevillano, E. (Eds.) Versus_Lessons from Vernacular Hetitage to Sustainable Architecture; CRAterre: Grenoble, France, 2014. 
16. Correia, M.; Dipasquale, L.; Mecca, S. (Eds.) Versus-Heritage for Tomorrow. Vernacular Knowledge for Sustainable Architecture; Florence University Press: Florence, Italy, 2014.

17. Correia, M.; Carlos, G.; Rocha, S. (Eds.) Vernacular Heritage and Earthen Architecture. Contributions for Sustainable Development; CRC-Taylor \& Francis Group: London, UK, 2014.

18. Mileto, C.; Vegas, F.; García-Soriano, L.; Cristini, V. (Eds.) Vernacular Architecture: Towards a Sustainable Future; CRCTaylor \& Francis Group: London, UK, 2015.

19. Mileto, C.; Vegas, F.; García-Soriano, L.; Cristini, V. (Eds.) Vernacular and Earthen Architecture: Conservation and Sustainability; CRC-Taylor \& Francis Group: London, UK, 2018.

20. Piesik, S. Habitat: Vernacular Architecture for a Changing Planet; Thames and Hudson: London, UK, 2017.

21. Buyle, M.; Braet, J.; Audernaet, A. LCA in the construction industry: A review. Int. J. Energy Environ. 2012, 6, $397-405$.

22. Cabeza, L.F.; Rincón, L.; Vilariño, V.; Pérez, G.; Castell, A. Life cycle assessment (LCA) and life cycle energy analysis (LCEA) of buildings and the building sector: A review. Renew. Sustain. Energy Rev. 2014, 29, 394-416. [CrossRef]

23. Gillott, M.; Spataru, C. Materials for energy efficiency and thermal comfort in the refurbishment of existing buildings. In Materials for Energy Efficiency and Thermal Comfort in Buildings; Woodhead Publishing Series in Energy; Elsevier: Amsterdam, The Netherlands, 2010; pp. 649-680.

24. Earl, J. Building Conservation Philosophy; Donhead: London, UK, 2003.

25. Hunt, R.; Suhr, M. Old Houses Handbook. A practical Guide to Care and Repair; SPAB: London, UK, 2008.

26. Suhr, M.; Hunt, R. A Practical Guide to Retrofitting for Energy-Efficiency E Sustainability; SPAB: London, UK, 2013.

27. Fatoric, S.; Biesbroek, R. Adapting cultural heritage to climate change impacts in The Netherlands: Barriers, interdependencies, and strategies for overcoming them. Clim. Chang. 2020, 162, 301-320. [CrossRef]

28. Fatoric, S.; Egberts, L. Realising the potential of cultural heritage to achieve climate change actions in The Netherlands. J. Environ. Manag. 2020, 274, 111107. [CrossRef]

29. Carroon, J. Sustainable Preservation: Greening Existing Buildings. Wiley Books: Hoboken, NJ, USA, 2010.

30. Ferreira, J.; Duarte Pinheiro, M.; de Brito, J. Economic and environmental savings of structural buildings refurbishment with demolition and reconstruction-A Portuguese benchmarking. J. Build. Eng. 2015, 3, 114-126. [CrossRef]

31. Adam, R. The greenest building is the one that already exists. Architects' Journal, 24 September 2019.

32. Gan, V.J.; Cheng, J.C.; Lo, I.M.; Chan, C.M. Developing a CO2-e accounting method for quantification and analysis of embodied carbon in high-rise buildings. J. Clean. Prod. 2017, 141, 825-836. [CrossRef]

33. Kim, Y.-C.; Zhang, Y.-L.; Park, W.-J.; Cha, G.-W.; Kim, J.-W.; Hong, W.-H. Analysis of waste generation characteristics during new apartment construction-considering the construction phase. Int. J. Environ. Res. Public Health 2019, 16, 3485. [CrossRef] [PubMed]

34. Akbarnezhad, A.; Xiao, J. Estimation and minimization of embodied carbon of buildings: A review. Buildings 2017, 7, 5. [CrossRef]

35. Vilches, A.; Garcia-Martinez, A.; Sanchez-Montañes, B. Life cycle assessment (LCA) of building refurbishment: A literature review. Energy Build. 2017, 135, 286-301. [CrossRef]

36. Pombo, O.; Rivela, B.; Neila, J. The challenge of sustainable building renovation: Assessment of current criteria and future outlook. J. Clean. Prod. 2016, 123, 88-100. [CrossRef]

37. Kamari, A.; Jensen, S.R.; Corrao, R.; Kirkegaard, P.H. A holistic multi-methodology for sustainable renovation. Int. J. Strat. Prop. Manag. 2018, 23, 50-64. [CrossRef]

38. Careccia, C.; D'Incognito, M. Life cycle assessment as a mean to grow awareness on the environmental impact of conservation. In Vernacular Architecture: Towards a Sustainable Future; Taylor and Francis: London, UK, 2015; pp. 185-191.

39. Blanco, J.; Serrano, B.; Ortega, L.; Soto, L. Strategies for energy retrofitting of vernacular architecture of Cabanyal-Canyamelar. In Vernacular Architecture: Towards a Sustainable Future; Taylor and Francis: Boca Raton, FL, USA, 2015; pp. 737-740.

40. Vegas, F.; Mileto, C. Km conservation. In Vernacular Architecture: Towards a Sustainable Future; Taylor and Francis: London, UK, 2015; pp. 737-740.

41. Luxton, C.; Bevan, S. Restored to Glory. A Guide to Renovating Your Period Home; BBC Books: London, UK, 2005.

42. Europa Nostra. Pilot Project for the Restoration of Vernacular Dwellings in Valencia. Available online: https://www. europeanheritageawards.eu/winners/pilot-project-restoration-vernacular-dwellings-valencia/ (accessed on 5 July 2021).

43. Vegas, F.; Mileto, C. Traditional techniques in masonry buildings at Rincón de Ademuz (Valencia). In Proceedings of the 10th Canadian Masonry Symposium, Banff, AB, Canada, 8-12 June 2005; pp. 674-683.

44. Lončar, S.; Vellinga, M. Rural regeneration. In Architectural Regeneration; Wiley Blackwell: Hoboken, NJ, USA.

45. United Nations Development Programme. The SGDS in Action. Available online: https://www.undp.org/publications/sdgsaction (accessed on 10 July 2021).

46. Vegas, F.; Mileto, C.; Diodato, M.; Soriano, J.G.; Giménez, C.G. Traditional structures made with gypsum pillars: A reasoned hypothesis. In Proceedings of the 4th International Congress on Construction History, Paris, France, 3-7 July 2012; Volume II, pp. 509-516.

47. Vegas, F.; Mileto, C.; Ivorra, S.; Baeza, F.J. Checking gypsum as structural material. Appl. Mech. Mater. 2011, 117-119, 1576-1579. [CrossRef]

48. Diodato, M. Estudio dendrocronológico de la casa n. 119 del Catastro de la aldea de Sesga; Universitat Politècnica de Valencia: Valencia, Spain, 2012; Unpublished Study. 
49. Pastor, P. Interview with Primitivo Pastor, former inhabitant of the house. 20 June 2007.

50. Vegas, F.; Mileto, C. Cultural identity \& built landscape. Pilot project for the restoration of traditional houses in Rincón de Ademuz (Valencia). Loggia Arquit. Restauración 2005, 17, 90-105.

51. Vegas, F.; Mileto, C.; Cristini, V.; Ruiz, J.R.; La Spina, V. Gypsum as reinforcement for floors: Conceptual approach. In Vernacular Heritage and Earthen Architecture; CRC Press: London, UK, 2014; pp. 389-394.

52. ISO (International Organization for Standardization). ISO 14040:2006 Environmental Management_Life Cycle Assessment_Principles and Framework; International Organization for Standardization: Geneva, Switzerland, 2006.

53. ISO (International Organization for Standardization). ISO 14044:2006 Environmental Management-Life Cycle AssessmentRequirements and Guidelines; International Organization for Standardization: Geneva, Switzerland, 2006.

54. CEN (European Committee for Standardization). EN, EN 15978:2011—Sustainability of Construction Works—Assessment of Environmental Performance of Buildings_Calculation Method, Int. Stand; European Committee for Standardization: Brussels, Belgium, 2011.

55. CEN (European Committee for Standardization). EN, N 15804:2012 + A2:2019—Sustainability of Construction Works—Environmental Product Declarations - Core Rules for the Product Category of Construction Products, Int. Stand.; European Committee for Standardization: Brussels, Belgium, 2012.

56. CTE (Technical Building Code). Spanish Building Technical Code, Real Decreto 314/2006 17 Marzo, BOE 74; CTE (Technical Building Code): Madird, Spain, 2006; pp. 11816-11831.

57. CEN (European Committee for Standardization). EN 16575:2014-10 Bio-Based Products_Vocabulary; European Committee for Standardization: Brussels, Belgium, 2014.

58. Frey, P.; Dunn, L.; Cochran, R.; Spataro, K.; McLennan, J.F.; DiNola, R.; Heider, B. The Greenest Building: Quantifying the Environmental Value of Building Reuse. 2016. Available online: www.cascadiagbc.org (accessed on 24 May 2021).

59. Hasik, V.; Escott, E.; Bates, R.; Carlisle, S.; Faircloth, B.; Bilec, M.M. Comparative whole-building life cycle assessment of renovation and new construction. Build. Environ. 2019, 161, 106218. [CrossRef]

60. Ecoinvent Database. Available online: https://www.ecoinvent.org (accessed on 24 May 2021).

61. Guinée, J.B.; Gorrée, M.; Heijungs, R.; Huppes, G.; Klejn, R.; de Koning, A.; van Oers, L.; Wegener Sleeswijk, A.; Suh, S.; Udo de Haes, H.A.; et al. Life Cycle Assessment_An Operational Guide to the ISO Standards_Parts 1, 2 and 3; Ministry of Housing, Spatial Planning and the Environment: Hague, The Netherlands, 2001.

62. Hoxha, E.; Passer, A.; Ruschi, M.; Mendes, M.; Saade, M.; Trigaux, D.; Shuttleworth, A.; Pittau, F.; Allacker, K.; Habert, G. Biogenic carbon in buildings: A critical overview of LCA methods. Build. Cities 2020, 1, 504-524. [CrossRef]

63. CEN (European Committee for Standardization). EN 16449 Wood and Wood-Based Products_Calculation of the Biogenic Carbon Content of Wood and Conversion to Carbon Dioxide; European Committee for Standardization: Brussels, Belgium, 2014.

64. Garcia, R.; Freire, F. Carbon footprint of particleboard: A comparison between ISO/TS 14067, GHG Protocol, PAS 2050 and Climate Declaration. J. Clean. Prod. 2014. [CrossRef]

65. Tomás Márquez, S. Análisis comparado de la estructura interna del presupuesto de restauración de una casa en Sesga, Ademuz; Valencia, Spain, 2021; Unpublished Work.

66. Vegas, F.; Mileto, C. Renovar Conservando. Manual de Restauración de la Arquitectura Tradicional del Rincón de Ademuz; Mancomunidad de Municipios del Rincón de Ademuz: Valencia, Spain, 2007.

67. Mileto, C.; Vegas, F. La restauración de la arquitectura tradicional como recuperación de los valores culturales y desarrollo económico. La experiencia en el Rincón de Ademuz (Valencia). In Actas del II Congreso Internacional de Patrimonio Cultural y Cooperación al Desarrollo, Proceedings of the II Congreso Internacional de Patrimonio Cultural y Cooperación al Desarrollo, Valencia, Spain, 8-10 June 2006; Universitat Politècnica de València (UPV): Valencia, Spain, 2006; pp. 256-265.

68. Guillaud, H. A heritage of reconciliation and of linkage between nature and culture. In From Vernacular to World Heritage; Florence University Press: Florence, Italy, 2020.

69. European Parliament. Despoblación y Cambios Demográficos. Available online: https:/ /www.europarl.europa.eu (accessed on 5 August 2021).

70. Pinilla, V.; Sáez, L.A. La Despoblación Rural en España: Génesis de un Problema y Políticas Innovadoras; Centro de Estudios sobre Despoblación y Desarrollo de Áreas Rurales (CEDDAR): Zaragoza, Spain, 2007. 